\title{
Turtle Neoplasm
}

National Cancer Institute

\section{Source}

National Cancer Institute. Turtle Neoplasm. NCI Thesaurus. Code C135001.

A neoplasm that occurs in a turtle. 